\title{
Mensaje del Rector
}

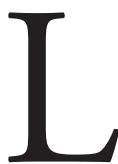

a Universidad Ricardo Palma es una institución que representa a la sociedad. Busca ser su conciencia, su alma y su faro, así como su reserva moral e intelectual. Es una institución líder que en circunstancias difíciles debe iluminar el camino del conocimiento. Nosotros nos esforzamos para que esta Universidad sobreviva a los tiempos y se mantenga flexible, adaptable a los cambios que se producen y se producirán en la sociedad. Ese es su futuro y ha quedado demostrado a través del éxito alcanzado en la acelerada transición a la educación virtual, que respondió a los retos planteados por los complejos fenómenos que nos presentan la sociedad y la naturaleza.

En estos momentos de crisis de nuestra civilización y alta incertidumbre, debido a la pandemia global provocada por el Covid 19, la Universidad

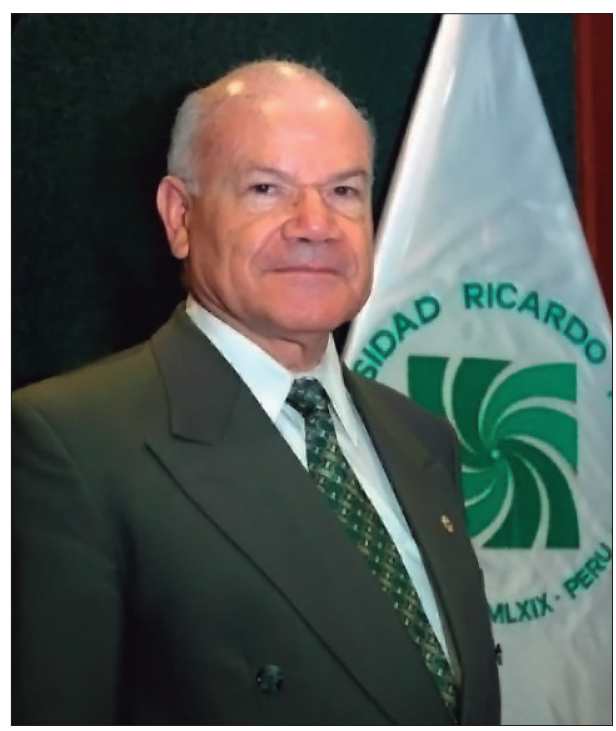
está redoblando esfuerzos para cumplir sus objetivos y contribuir con el país en todos los aspectos. Promovemos el espíritu interdisciplinario, el humanismo y la realización personal como requisitos indispensables para lograr profesionales íntegros al servicio de la humanidad y en pos de la sostenibilidad de la vida.

Nuestra misión institucional se viene cumpliendo con éxito. Nuestras facultades cuentan con los mejores reconocimientos nacionales e internacionales. La Facultad de Ingeniería cuenta con la acreditación internacional otorgada por la Accreditation Board for Engineering and Technology (ABET) y las acreditaciones nacionales dadas por el Sistema Nacional de Evaluación, Acreditación y Certificación de la Calidad Educativa (SINEACE), la Superintendencia Nacional de Educación Superior Universitaria (SUNEDU), y el Instituto de Calidad y Acreditación de Programas de Computación, Ingeniería y Tecnología (ICACIT). La plana docente estará conformada por maestros y doctores expertos en enseñanza universitaria y con publicaciones indexadas y otras expresiones de creación cultural. Hemos logrado el intercambio de profesores y estudiantes con universidades extranjeras en todas sus carreras profesionales y una importante participación en la cooperación internacional.

Con especial satisfacción, recibimos esta nueva edición de la revista Perfiles de Ingeniería, que publica destacadas investigaciones, proyectos y buenas prácticas del desarrollo de la ingeniería industrial, informática, civil, electrónica y mecatrónica. Felicito especialmente al Decano de la facultad, al equipo editorial y a todos los investigadores, que han hecho posible esta nueva y siempre necesaria edición.

Dr. IvÁN RodríGuez Chávez Rector de la URP 